\title{
CORRESPONDENCE
}

\section{Asian education must change to promote innovative thinking}

As Asian economies ramp up $R \& D$, and high-tech companies relocate to China and India, Asian science looks unstoppable - apart from one last hurdle: a shortage of local talent. A radical change in Asia's education culture is needed to foster the human capital necessary for innovationled economies.

The exam-centric Asian education system has created a workforce more adept at imitation than innovation (W. Lim Science 327, 1576-1577; 2010). Asiabased scientists without Western collaborators therefore seldom publish in highly cited, indexed journals. No Asian nation is represented among the top 20 , ranked by the average number of citations per published paper.

A critical mass of creative researchers is required to sustain research and attract talent. For decades, Asian countries have sent their best to the West for training in science and technology. Those who return are valued for their initiative and creativity, and currently form the bulk of research leaders and productive scientists. But many émigrés opt to remain overseas, where creative potential is higher. Except for most Japanese laureates, virtually all science Nobel Prizewinners of Asian descent did their groundbreaking work in the West, and remained there. Countries that lure prominent foreign scientists find their impact on local researchers as unpredictable as the length of time they are willing to stay.

Asian governments recognize that the solution is to develop homegrown scientific talent. They have been adapting their national school curricula to fit new global realities. China and Japan, for example, have been moving away from a centralized curriculum.

Suitable science students should join a stream that feeds into the best universities. They should mainly be taught using problem-based and enquirybased learning, which will develop their powers of investigation and critical thinking. Grades should depend on active contribution during group-based learning sessions, to change the focus from competitive examination to collaborative learning.

Only when these reforms are in place will Asian schools be able to progress beyond content knowledge to nurture the innovative thinking necessary to sustain the rise of Asian science. William K. Lim Faculty of Medicine and Health Sciences, Universiti Malaysia Sarawak, 93150 Kuching, Sarawak, Malaysia

e-mail:kslim@fmhs.unimas.my

\section{Volcanic ash should not be presumed harmless in long term}

The scientific community and public authorities need to thoroughly investigate the potential effects of the potential effects of the volcanic ash cloud originating in Iceland and now covering large areas of Europe (Nature 464, 1253; 2010).

Although the associated climate and meteorological phenomena are being well documented, questions arise as to what the environmental and public-health effects might be in the longer term. For example, micro- and nano-sized particles and residues could contaminate food, fields and water.

Samples can readily be obtained from the atmosphere, as well as from industrial and domestic filters in machinery. These need to be analysed for carbon and metallic particles, and the ash tested for radiation, because the volcano explosion arose from deep geological deposits that may contain radioisotopes. This research and monitoring could be undertaken by public-health departments.

It cannot be assumed that volcanic ash has no dangerous effects. It is the duty of public authorities to investigate and report back to the public.

Sergio Mascarenhas Nanoagri2010, Instituto de Estudos Avançados, USP São Carlos, São Carlos 13.560-590, SP Brazil

e-mail: sergiomascarenhas 28 @gmail.com

Luiz H. C. Mattoso National Nanotechnology Lab for Agriculture, LNNA, Embrapa, São Carlos, Brazil

\section{Making the case for low-template DNA analysis}

Your News Feature 'DNA's identity crisis' (Nature 464, 347-348; 2010) implies that the UK Court of Appeal in the Reed brothers' case cast doubt on the validity of analysing small amounts of DNA. This is misleading and not borne out by the judgement of the Court (see go.nature.com/msMgum).

Analysis by independent scientists commissioned by my office (B. Caddy et al. A Review of the Science of Low Template DNA Analysis Home Office Forensic Science Regulation Unit, 2008) concluded that the science supporting the delivery of lowtemplate DNA analysis - a term used to cover different methods, including the low-copy-number (LCN) method - is sound and has been validated in accordance with scientific principles. This view has been upheld, with regard to $\mathrm{LCN}$, in considered judgements by Courts of Appeal in London and New Zealand, and the Supreme Court of the State of New York.

In my response as Forensic Science Regulator (see go.nature. com/y2ApQ2), I addressed all 21 recommendations of the review, referring several of these recommendations to my Quality Standards Specialist Group and my DNA Specialist Group for monitoring and/or further advice. I also commissioned further work to develop a consensus on the core interpretation methods for low-template DNA analysis.

The Reed brothers abandoned their appeal on the reliability of low-template DNA evidence using the LCN process. The Court nonetheless heard evidence on this and other issues, including one of primary and secondary transfer of DNA, from $A$. Jamieson, B. Budowle, A. M. T. Linacre and $\mathrm{V}$. Tomlinson (an officer of the Forensic Science Service). Their Lordships ruled that challenging the validity of the method was not justified for DNA amounts above the stochastic threshold of 100-200 picograms. They did not accept the counter argument of Budowle and Jamieson that experts cannot form an opinion on the transfer of DNA in low-template cases.

In an admissibility hearing on LCN DNA analysis in the Supreme Court for the State of New York, the Honorable Robert J. Hanophy ruled in February that "low-copynumber DNA testing ... passes the standard enunciated in Frye and is therefore admissible at trial". This standard includes the requirement for general acceptance in the scientific community (see go.nature.com/ylaVgK).

In March, the Court of Appeal of New Zealand dismissed an attempt to have LCN DNA evidence ruled inadmissible as "a minority view" (see go.nature.com/rplnb1). The Court ruled that "on the current state of the law, we consider that blanket attacks on the science as such are not sustainable.... [In] $R$ $\checkmark$ Lepper, ... the proposition was advanced that LCN DNA analysis is unreliable [see go.nature.com/ ImRTr2]. That proposition has since been specifically rejected by this Court. Crown counsel note that LCN analysis has been accepted in trial evidence in the USA, UK, Australia and Sweden."

In the case of the Reed brothers, the Court of Appeal provided a considered judgement that I recommend as an informed review of the current state of DNA technology in criminal prosecutions.

Andrew Rennison Home Office Forensic Science Regulation Unit, Queensway, Birmingham B1 1TT, UK e-mail: andrew.rennison4 @homeoffice.gsi.gov.uk 